\title{
Drainage ditches as important habitat for species diversity and rare species of aquatic beetles in agricultural landscapes (Insecta: Coleoptera)
}

\author{
Daniel ROLKE, ${ }^{1{ }^{*}}$ Birgit JAENICKE, ${ }^{1,2}$ Jobst PFAENDER, ${ }^{1}$ Udo ROTHE ${ }^{1}$ \\ ${ }^{1}$ Naturkundemuseum Potsdam, Breite Str. 11/13, 14467 Potsdam; ${ }^{2}$ Senckenberg Deutsches Entomologisches Institut, Eberswalder \\ Straße 90, 15374 Müncheberg, Germany \\ ${ }^{\S}$ Current address: Landesamt für Umweltschutz Sachsen-Anhalt, Reideburger Straße 47, 06116 Halle (Saale), Germany \\ *Corresponding author: daniel.rolke@1au.mlu.sachsen-anhalt.de
}

\begin{abstract}
Agricultural drainage ditches are common structures in cultivated lowland areas across Europe. These artificial linear water bodies are interconnected to form networks that can offer valuable habitats for many water associated organisms. The current study contributes to the knowledge of aquatic Coleoptera biodiversity associated with artificial drainage ditches. Fundamental ecological and faunistical findings were combined with aspects relevant for applied nature conservation. Adult beetles were sampled at 124 sampling locations belonging to seven study sites in the federal state of Brandenburg, Germany. With 108 taxa out of 10 families the studied ditches showed a high species richness. Taxa associated with eutrophic conditions dominated with the dytiscid Hydroporus palustris as the most abundant species. In terms of $\beta$-diversity, a moderate turnover between the study sites could be observed. Although the sampling locations showed some degree of variability concerning habitat characteristics, measured environmental parameters only weakly explained observed differences in community composition. Beside taxonomical characterization of beetle diversity, aspects of functional diversity were analyzed. Interestingly, individuals with reduced flight ability were dominant. Because the predaceous family Dytiscidae dominated, beetles were mainly integrated as carnivores in the food web of ditches. Throughout the study, $13.0 \%$ threatened as well as $18.4 \%$ rare taxa could be recorded, referring to the German fauna of aquatic beetles. This may underpin the need to include agricultural drainage ditches into conservation management.
\end{abstract}

Key words: Biodiversity; ditches; Coleoptera; community; conservation; functional diversity.

Received: April 2018. Accepted: July 2018.

\section{INTRODUCTION}

Intensive modern agriculture is accompanied by substantial changes in the landscape structure that often results in a decrease of habitat and biodiversity (Fischer and Lindenmayer, 2007). For instance, many wetlands in lowland areas across Europe were drained by the establishment of ditch networks, to enable and enhance intense agricultural land use (Herzon and Helenius, 2008). However, agricultural drainage ditches in poorly structured landscapes can offer valuable habitats for a remarkable diversity of water associated organisms, including rare and endangered species (Moroz, 1993; Painter, 1999; Armitage et al., 2003; Williams et al., 2003; Davies et al., 2008a, 2008b; Verdonschot et al., 2011; Clarke, 2015). Despite their enormous additive size, these artificial water bodies received little attention in ecological studies in the past. In the last years an increasing number of studies now focused on the potential biodiversity value of ditches (Herzon and Helenius, 2008). The knowledge of aquatic organisms within ditches is also important since these anthropogenic water bodies underlie regular management activities to prevent silting up (Twisk et al., 2000). Maintenance measures like the removal of mud and/or macrophytes are essential to sustain ditch function, although they may cause problems regarding an impairment of populations of endangered species. Therefore, the development of sustainable management plans for both, ditch maintenance and biodiversity conservation, relies on substantial knowledge about drainage ditch biodiversity and its habitat dependence.

Aquatic beetles are suitable indicators for the overall insect diversity in aquatic ecosystems (SánchezFernández et al., 2006; Pakulnicka et al., 2015a). This highly diverse group (Jäch and Balke, 2008) makes up a considerable proportion of macroinvertebrates in both lentic and lotic waters (Briers and Biggs, 2005; SánchezFernández et al., 2006; Vaikre et al., 2015; Hill et al., 2016). Aquatic Coleoptera comprise a mixture of systematically different families. Ten 'true water beetle' families (sensu Jäch 1998) are present in agricultural drainage ditches in Germany (Braasch et al., 2000): Dryopidae, Dytiscidae, Gyrinidae, Haliplidae, Helophoridae, Hydraenidae, Hydrochidae, Hydrophilidae, Noteridae and Spercheidae. These families together are represented by approximately 320 species in Germany 
(excluded are terrestrial species of the family Hydrophilidae) (Spitzenberg et al., 2016). Around 30\% of the overall aquatic Coleoptera occurring in Germany have been categorized, to different degrees as threatened according to the corresponding Red List (Spitzenberg et al., 2016).

A detailed knowledge about the general community structure and the occurrence of threatened Coleoptera species in drainage ditches provide valuable information about the ecological and conservation value of these artificial water bodies (Herzon and Helenius, 2008; Verdonschot et al., 2011; Hill et al., 2016).

Beetle communities can be described by their taxonomic diversity, relative abundance and spatial heterogeneity (e.g. Verdonschot et al., 2011; Hill et al., 2016). Following Whittaker (1972), the spatial distribution of biodiversity can be measured at different scales, the $\alpha-\beta$ - and $\gamma$-diversity. First, the species diversity within a particular local community or habitat is referred as $\alpha$-diversity and is most influenced by local environmental factors. Second, the comparison of species diversity between different habitats or localities is called $\beta$-diversity and is much dependent on the spatial scale considered (Barton et al., 2013). Also, $\beta$-diversity is affected by response of species to environmental gradients (Heino, 2009). Finally, $\gamma$-diversity is seen as the total species diversity across a certain region. Taken together, the consideration and evaluation of biodiversity at different levels may allow a comprehensive picture of the spatial distribution of aquatic beetles in agricultural ditch networks.

Taxonomic diversity provides important information about the relationship and composition of taxa within communities. However, its significance is limited regarding the participation of the particular community in ecosystem processes. The functional diversity concept has been developed to overcome this limitation and to complement the description of communities (Mouillot et $a l ., 2006)$. Thus, species are grouped to functional units based on morphological and biological traits, such as flight ability, locomotion type or the mode of utilizing food resources.

Different habitat parameters, like e.g. water temperature, $\mathrm{pH}$, conductivity, hydroperiod or the presence of predator regimes are known to influence invertebrate assemblages (Batzer and Wissinger, 1996; Fairchild et al., 2000; Heino, 2009; Leslie et al., 2012; Verdonschot et al., 2012a; Whatley et al., 2015; Ieromina et al., 2016a, 2016b). However, only few studies focused on the relationship between environmental factors and the community structures of aquatic beetles (Menetrey et al., 2011; Vamosi and Wohlfahrt, 2014; Guareschi et al., 2015). Linking habitat data with differences in beetle assemblages can provide important insights into processes that influence community composition in agricultural ditches. Further, the environmental characterization of drainage ditches may allow a proper placement of the results in context to other relevant field studies, as drainage ditches can differ in their morphology and physico-chemical parameters across different European regions (Davies et al., 2008a).

Here, the aquatic beetle community of agricultural drainage ditches in northeast Germany was investigated, to evaluate i) the ecological value of these artificial water bodies for this group of insects and ii) the conservation value of this habitat for rare and endangered beetle species.

Therefore, the taxonomic and functional diversity of the beetle community in the ditches have been investigated. Habitat parameters have been studied to identify major differences between ditches and their possible impact on the composition of beetle assemblages. The presence of rare and endangered beetle species was used to assess the conservation value and address the need to increasingly include artificial ditches in conservation management.

\section{METHODS}

\section{Study area}

Agricultural drainage ditches at seven study sites within an area of $500 \mathrm{~km}^{2}$ have been investigated in northeast Germany (federal state of Brandenburg) within the so called 'Havelland' area (Fig. 1). The greatest distance between two study sites was $35 \mathrm{~km}$ while the smallest was $3.5 \mathrm{~km}$. At each study site, 11 to 22 sections of a length between 50 and $100 \mathrm{~m}$ have been sampled (in total 124 locations, Tab. 1). The smallest distance between two sampling locations was approximately $70 \mathrm{~m}$. These artificial linear water bodies constituted networks, usually consisting of several small to medium sized ditches, connected to a main collection ditch or channel, which releases the water to an adjacent flowing water system (Clarke, 2015). The studied drainage ditches were stagnant to temporarily slow flowing. The water current depends on pumping activity at the outlet of the drainage system. Most ditches are permanently filled with water. However, ditches in the periphery may dry up during periods without precipitation. Here, only ditches containing water at the time of sampling were included in this study.

A separate ditch network with its own main collection ditch and pumping station has been considered as one study site.

\section{Data collection}

Data were collected during 25 sampling days between 31 March and 08 August 2016. This timeframe has been chosen as spring and summer are known for their high 
taxon richness of macroinvertebrates in lentic waters (Verdonschot et al., 2012b; Hill et al., 2016) and to exclude an interfering with ditch management activities, because cleaning and desludging regularly takes place in autumn.

\section{Environmental characterization}

The environmental data were collected together with the beetle sampling at each sampling location. The morphology of ditches was characterized by the width, depth, thickness of the sediment layer and thickness of the water layer. Four physico-chemical parameters (water temperature, $\mathrm{pH}$, electrical conductivity and dissolved oxygen), have been measured, using a HQ40D ${ }^{\circledR}$ Multimeter with different HQD Intellical ${ }^{\circledR}$ Electrodes (Hach Lange, Düsseldorf, Germany). The number of fish species and individuals was assessed by electrofishing (backpack device with a single anode using a pulsed direct current; IG 200, Hans Grassl, Schönau am Königsee, Germany). Fish

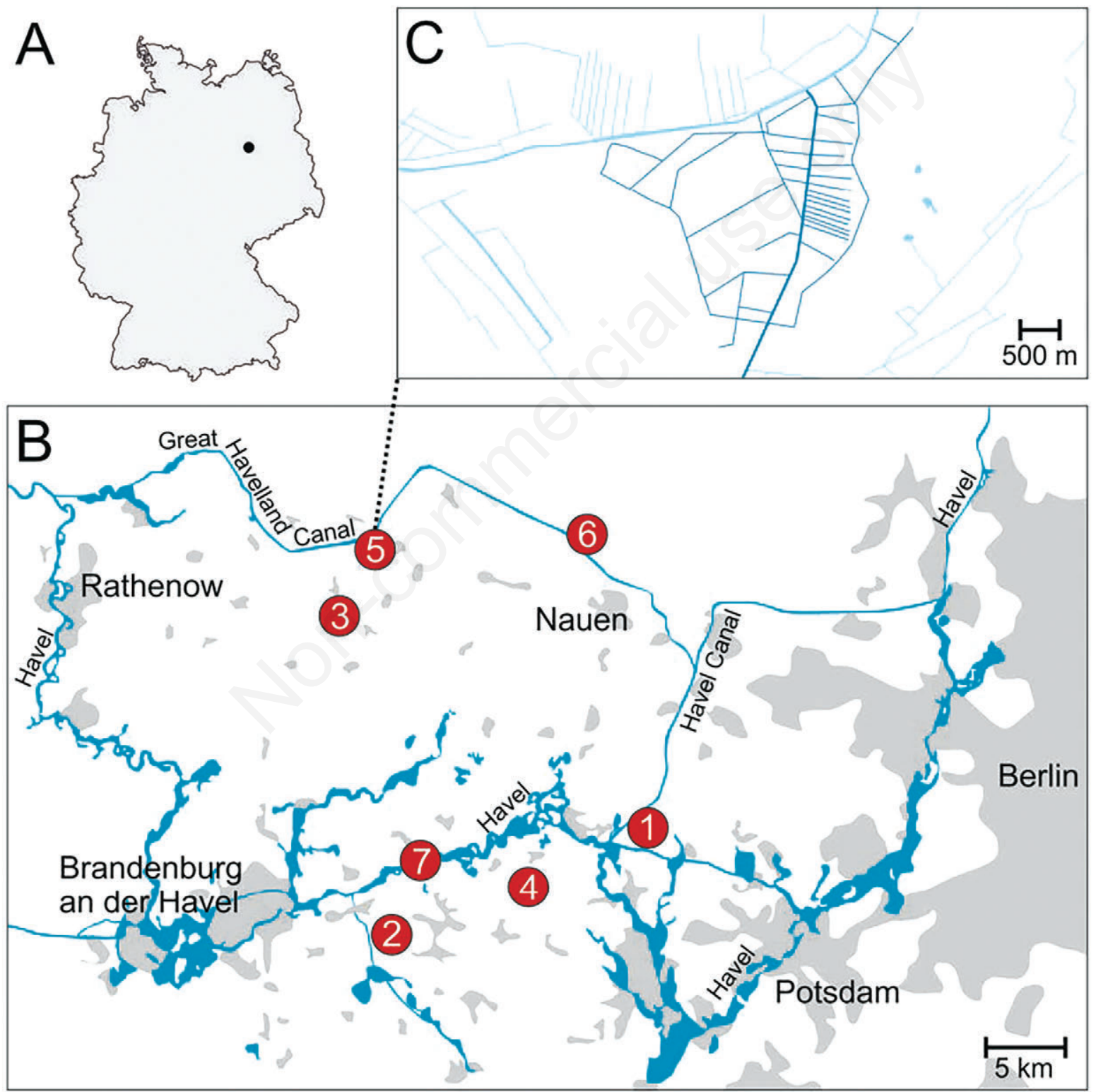

Fig. 1. Location of the study area in northeast Germany (A). Study sites were situated within the so called 'Havelland' area west of Berlin in the vicinity of the river 'Havel' (with lake-like expansions) and the canals 'Great Havelland Canal' and 'Havel Canal' (B). More detailed illustration of one of the study sites with blue lines indicating agricultural drainage ditch system. Study site ditches highlighted, nearby water bodies faded (C). 
was determined to species level in the field.

\section{Sampling}

Adult aquatic beetles were sampled at all 124 sampling locations, using a hand net (square opening with a frame size of $25 \times 25 \mathrm{~cm}$ and a mesh size of $500 \mu \mathrm{m}$ ), which has been swept several times at the edge of the ditch, through submerged vegetation, floating mats of algae and the open water body (multi-habitat sampling). Net content was spread across a white plastic tray $(570 \times$ $380 \times 160 \mathrm{~mm}$ ) and searched for adult beetles for $5 \mathrm{~min}$. This procedure was repeated six times at each sampling location, leading to one pooled sample per location (124 samples in total).

\section{Data processing and analysis}

\section{Environmental characterization}

Mean numbers of the measured environmental parameters were compared among the study sites using either Kruskal-Wallis test or one-way analysis of variance (ANOVA) depending on normal distribution of data checked by Shapiro-Wilk test.

\section{Taxonomical adjustment}

The collected specimens were determined to the lowest feasible taxonomical level within the frame of the study. Determination to species level was possible for $79.0 \%$ of the individuals. The remaining specimens could be identified to genus or subgenus level, or belonged to species pairs or species complexes. Determination only to genus level was performed for all Dryops (Dryopidae), some Limnebius, some Ochthebius (both Hydraenidae) and all female Laccobius (Hydrophilidae). Females of the subgenus Haliplus sensu stricto (Haliplidae) could be determined to subgenus level, whereas all males could be identified to species level by the examination of the genitalia. Species pairs that were not separated within the study were Helophorus aquaticus/aequalis, Helophorus flavipes/obscurus, and Helophorus minutus/paraminutus (all Helophoridae). Furthermore, specimens of the recently separated Hydrobius fuscipes complex (Fossen et al., 2016) could not be determined to species level. To avoid information overlap within the following analyses (diversity and similarity indices, multivariate statistics), the dataset has been taxonomically adjusted according to Nijboer and Verdonschot (2000), Schmidt-Kloiber and Nijboer (2004), Vlek et al. (2004) and Verdonschot et al. (2012b). Hence, when the proportion of specimens identified to species level within the same (sub)genus was less than $20 \%$, the lower taxonomic level was aggregated to the higher taxonomic level. However, species pairs and the Hydrobius fuscipes complex were treated as such.

\section{Diversity and faunal comparison indices}

The $\alpha$ - and $\gamma$-diversity was evaluated using the inverted Simpson index, the Shannon index and the evenness (Tab. S1). These indices are common indices in biodiversity research (Morris et al., 2014), addressing slightly different aspects of diversity (i.e., different weighing of abundant taxa). Dominance of taxa was categorized using the classification of Engelmann (1978) (Tab. 2).

The species similarity ( $\beta$-diversity) between the study sites were pairwise evaluated using the Jaccard index and the Sørensen index (Tab. S1). The Renkonen index and

Tab. 1. Number of sampling locations, environmental parameters (mean \pm standard deviation) at the study sites.

\begin{tabular}{|c|c|c|c|c|c|c|c|c|}
\hline \multirow[t]{2}{*}{ Parameter } & \multicolumn{7}{|c|}{ Study site } & \multirow[t]{2}{*}{ Total } \\
\hline & 1 & 2 & 3 & 4 & 5 & 6 & 7 & \\
\hline Number of sampling locatio & ons & 20 & 22 & 21 & 21 & 16 & 11 & 124 \\
\hline Mean width (m) & $2.89 \pm 1.83$ & $3.31 \pm 1.17$ & $2.40 \pm 0.67$ & $2.73 \pm 0.98$ & $3.02 \pm 1.68$ & $4.03 \pm 0.82$ & $2.50 \pm 0.92$ & $2.98 \pm 1.28$ \\
\hline Mean depth (m) & $1.07 \pm 0.23$ & $1.47 \pm 0.45$ & $0.83 \pm 0.25$ & $1.18 \pm 0.30$ & $1.04 \pm 0.30$ & $1.33 \pm 0.23$ & $0.90 \pm 0.25$ & $1.12 \pm 0.37$ \\
\hline $\begin{array}{l}\text { Thickness of sediment } \\
\text { layer }(\mathrm{m})\end{array}$ & $0.35 \pm 0.16$ & $0.49 \pm 0.30$ & $0.27 \pm 0.13$ & $0.45 \pm 0.17$ & $0.57 \pm 0.21$ & $0.59 \pm 0.15$ & $0.47 \pm 0.25$ & $0.46 \pm 0.23$ \\
\hline $\begin{array}{l}\text { Thickness of water } \\
\text { layer }(\mathrm{m})\end{array}$ & $0.60 \pm 0.26$ & $0.81 \pm 0.29$ & $0.36 \pm 0.11$ & $0.49 \pm 0.10$ & $0.24 \pm 0.13$ & $0.52 \pm 0.12$ & $0.35 \pm 0.12$ & $0.48 \pm 0.25$ \\
\hline Water temperature $\left({ }^{\circ} \mathrm{C}\right)$ & $18.19 \pm 6.15$ & $12.26 \pm 1.13$ & $15.28 \pm 3.31$ & $11.15 \pm 1.63$ & $22.70 \pm 3.33$ & $17.63 \pm 1.08$ & $16.55 \pm 3.01$ & $16.04 \pm 4.92$ \\
\hline $\mathrm{pH}$ & $7.45 \pm 0.65$ & $7.12 \pm 0.32$ & $7.29 \pm 0.42$ & $7.75 \pm 0.36$ & $7.85 \pm 0.32$ & $7.67 \pm 0.19$ & $6.98 \pm 0.22$ & $7.46 \pm 0.48$ \\
\hline $\begin{array}{l}\text { Electrical conductivity } \\
\left(\mu \mathrm{Scm}^{-1}\right)\end{array}$ & $823.15 \pm 100.02$ & $784.30 \pm 82.48$ & $566.33 \pm 81.30$ & $860.00 \pm 77.07$ & $1201.95 \pm 300.77$ & $1048.25 \pm 247.78$ & $790.27 \pm 38.84$ & $926.66 \pm 269.07$ \\
\hline Dissolved oxygen $\left(\mathrm{mgl}^{-1}\right)$ & $6.52 \pm 4.81$ & $5.93 \pm 2.17$ & $7.91 \pm 3.21$ & $10.74 \pm 2.67$ & $7.66 \pm 3.59$ & $3.65 \pm 2.49$ & $0.39 \pm 0.29$ & $6.69 \pm 4.10$ \\
\hline Number of fish individuals & $108.77 \pm 146.77$ & $12.40 \pm 12.43$ & $60.91 \pm 123.91$ & $28.95 \pm 53.93$ & $170.43 \pm 255.74$ & $30.75 \pm 100.03$ & $47.55 \pm 71.57$ & $66.16 \pm 142.98$ \\
\hline Number of fish species & $2.62 \pm 1.45$ & $2.95 \pm 1.73$ & $2.55 \pm 2.24$ & $2.76 \pm 1.48$ & $4.10 \pm 3.35$ & $1.19 \pm 1.28$ & $1.64 \pm 1.12$ & $2.66 \pm 2.18$ \\
\hline
\end{tabular}


the Wainstein index (Tab. S1) were used to compare the dominance identities of pairs of study sites (Mühlenberg, 1989).

\section{Morphological and ecological traits}

Different morphological and ecological traits were analyzed, to further characterize the community of aquatic beetles. The flight ability of each taxon of the aquatic Adephaga (Dytiscidae, Haliplidae, Noteridae, Gyrinidae; hereafter referred as 'Hydradephaga'; 62.5\% of individuals, $61.5 \%$ of taxa) was categorized (Tab. 2).

Other functional traits analyzed include the locomotion type (swimmer, water surface locomotion, crawler, sediment burrower), feeding group (predator, piercer of plant and/or algal cells, collector-gatherer, shredder) and trophic level (detrivore, herbivore, carnivore). A trait database was provided by Verdonschot (Wageningen, The Netherlands) which contains information already used for similar analyses (Verdonschot et al., 2011, 2012b) and was complemented by information about additional species (Angus, 1992; Nilsson and Holmen, 1995; van Vondel and Dettner, 1997; Hebauer and Klausnitzer, 2000; Bergsten et al., 2012). For each taxon, each of the modalities per trait was assigned a coefficient ranging from 0 to 1 as described by (Ieromina et al., 2016a). Thus, if a taxon is characterized by two different modalities per trait (e.g., 60\% swimming and $40 \%$ crawling as type of locomotion) the modalities were assigned a coefficient according to their proportion (e.g., swimmer $=0.6$ and crawler $=0.4$; whereas water surface and sediment burrower $=0$, respectively). Subsequently, the trait modality coefficients per taxon were weighted by the taxon abundance (multiplication of coefficient by the $\log (\mathrm{x}+1)$ transformed number of individuals) and by the individual biomass (multiplication by the maximum body size obtained from literature). This weighing reduces the immoderate impact of small and rare species (Ieromina et al., 2016a). Trait data were analyzed for all taxa with the exception of Dryopidae $(0.47 \%$ of individuals) and the three species of the genus Cercyon (Hydrophilidae, one individual each, $0.06 \%$ of individuals) because incomplete information was available.

\section{Endangerment and rarity}

Information about the endangerment and rarity of the taxa was taken from the German Red List of aquatic beetles (Spitzenberg et al., 2016) (Tab. 2). Only taxa that could be unequivocally assigned to one of the categories were taken into account. For the remaining taxa either no information was available or the determination to a higher taxonomic level did not allow a proper assignment. Taken

Tab. 2. Categorization of taxa according to different parameters and traits.

\begin{tabular}{|c|c|c|}
\hline Parameter & Categories & Reference \\
\hline Dominance & $\begin{array}{l}\text { i) Main taxa } \\
\text { eudominant }(>32.0 \%) \\
\text { dominant }(10.0-31.9 \%) \\
\text { subdominant }(3.2-9.9 \%) \\
\text { ii) Companion taxa } \\
\text { recedent }(1.0-3.1 \%) \\
\text { subrecedent }(<1.0 \%)\end{array}$ & (Engelmann, 1978) \\
\hline Flight ability & $\begin{array}{l}\text { Flightless (1) } \\
\text { Variable (2a) } \\
\text { Presumably variable (2b) } \\
\text { Flier (3) } \\
\text { Good flier (4) } \\
\text { Unknown (?) }\end{array}$ & (Kehl and Dettner, 2007) \\
\hline Endangerment & $\begin{array}{l}\text { Extinct }(0) \\
\text { Critically endangered (1) } \\
\text { Endangered (2) } \\
\text { Vulnerable (3) } \\
\text { Near threatened (v) } \\
\text { Data deficient }(\mathrm{d}) \\
\text { Least concern }(*)\end{array}$ & (Spitzenberg et al., 2016) \\
\hline Rarity & $\begin{array}{l}\text { Abundant (sh) } \\
\text { Common (h) } \\
\text { Moderately common (mh) } \\
\text { Rare (s) } \\
\text { Very rare (ss) }\end{array}$ & (Spitzenberg et al., 2016) \\
\hline
\end{tabular}


together, the endangerment of $91.7 \%$ of the taxa $(85.0 \%$ of individuals) as well as the rarity of $93.6 \%$ of the taxa ( $90.1 \%$ of individuals) could be evaluated.

\section{Multivariate analyses}

Different ordination methods were used to detect structures and patterns within the data set. Beetle abundance data were $\log (\mathrm{x}+1)$ transformed and habitat data were standardized to increase normality and comparability prior to the analyses. Initially, a detrended correspondence analysis (DCA) was performed to test for either a linear or unimodal distribution of taxa along environmental gradients depending on the axis length of the first DCA axis (axis length $>4$ indicates unimodal model, axis length $<3$ indicates linear model as appropriate, ter Braak and Šmilauer 2002). The length of the first DCA axis on taxa abundance data was 2.83 . Hence, linear ordination models as redundancy analysis was performed to analyze the impact of the measured environmental factors on the taxa composition. A direct (canonical) ordination method (RDA) was used. An ANOVA like permutation test (based on 999 unrestricted permutations) was performed to test for the significance of all RDA axes and the first RDA axis, respectively. The permutation test reveals if the abundance data are significantly related to the environmental data included in the RDA. Based on RDA, variance partitioning was applied to divide the total variance explained by all the collected environmental parameters into proportions of variance explained by groups of these parameters (as used in similar studies, e.g., Ieromina et al., 2016b). Four groups of environmental parameters were defined: 'ditch morphology' (M) including width, depth, thickness of water layer and thickness of sediment layer, 'water chemistry' $(\mathrm{C})$ including water temperature, $\mathrm{pH}$ and electrical conductivity, 'presence of fish' (F) including numbers of fish individuals and fish species, and 'time' $(\mathrm{T})$. Thus, the variance in total beetle community composition was divided into six aspects: variance explained respectively by $\mathrm{M}, \mathrm{C}, \mathrm{F}, \mathrm{T}$, shared variance between $\mathrm{M}, \mathrm{C}, \mathrm{F}$ and $\mathrm{T}$, and unexplained (residual) variance. The total variance in the composition of the beetle community (sum of constrained and unconstrained eigenvalues) was obtained by an RDA including all environmental parameters as explanatory variables. To gain the proportion of variance explained by the different groups of environmental parameters $(\mathrm{M}$, C, F, T), separate partial RDAs were performed including one group as explanatory variables and the remaining as covariates, respectively. The proportion of explained variance shared by $\mathrm{M}, \mathrm{C}, \mathrm{F}$ and $\mathrm{T}$ was calculated by subtracting each proportion explained by the parameter groups alone from the total explained variance.

\section{Software}

Univariate statistics (Shapiro-Wilk test of normal distribution, comparison of means by Kruskal-Wallis test and one-way ANOVA, linear correlation, linear regression) as well as the calculation of diversity indices was performed using PAST software (ver. 3.15, Hammer et al., 2001) and GraphPad Prism (ver. 6.04, GraphPad Software, La Jolla, CA, USA). Multivariate statistics (DCA, RDA, permutation test, variance partitioning) was performed using PAST as well as the package 'vegan' (ver. 2.3-5, Oksanen et al., 2016) for the program RStudio (ver. 1.0.136). The taxa accumulation curve was calculated using the program AccuCurve (ver. 1.0; Drozd and Novotny, 2010). Averaged values are given as mean \pm standard deviation.

\section{RESULTS}

\section{Environmental characterization}

In total, 124 sampling locations in agricultural drainage ditches were investigated (Tab. 1, Fig. S1). The width of the surveyed ditches varied between 0.7 and $7.5 \mathrm{~m}$ and differed significantly between the sampling sites (KruskalWallis test, $\mathrm{P}=0.002$ ). The depth ranged between 0.3 and $2.5 \mathrm{~m}(1.1 \pm 0.4 \mathrm{~m})$. The mean depth varied significantly in a pairwise comparison between the study sites (one-way ANOVA: $\mathrm{P}<0.0001)$. The ditches showed layers of sediment between 0.1 and $1.1 \mathrm{~m}$ and an above water layer from 0.1 to $1.4 \mathrm{~m}$. The sediment layer as well as the water layer differed significantly between the study sites (both Kruskal-Wallis test: $\mathrm{P}<0.0001$ ) (Tab. 1, Fig. S1).

The water temperature during the study varied between 8.3 and $26.1{ }^{\circ} \mathrm{C}$. As expected, the water temperature was highly correlated with the time of the season (linear correlation: Pearson's $\mathrm{r}=0.452, \mathrm{P}=0.003$ ) and differed significantly between the study sites (Kruskal-Wallis test, $\mathrm{P}<0.0001$ ). $\mathrm{PH}$ values varied between 6.4 and 8.8 and differed significant between the study sites (one-way ANOVA: $\mathrm{P}=0.009$ ) as well as the electrical conductivity (Kruskal-Wallis test: $\mathrm{P}<0.0001$ ) with a minimum of $495 \mu \mathrm{Scm}^{-1}$ and a maximum of 1887 $\mu \mathrm{Scm}^{-1}$. Also regarding the measurements of dissolved oxygen, the study sites differed significantly (KruskalWallis test: $\mathrm{P}<0.0001$ ) with numbers between 0.2 and 17.0 $\mathrm{mgl}^{-1}$ (Tab. 1, Fig. S1).

Physico-chemical variables can show seasonal and/or daily fluctuations. Since habitat measurements were done only once per sampling location they should be interpreted with care. However, because the measurements were performed at the same time as beetle sampling, they describe the actual environmental conditions the beetle assemblages were exposed to at that certain time.

Fish was present at $91.9 \%$ of all sampling locations. 
The number of fish individuals per sampling location ranged between 0 and 1,033 with significant differences in the abundance between the study sites (Kruskal-Wallis test: $\mathrm{P}=0.0005)$. In line with the fish abundance, the number of fish species differed significantly between the study sites (Kruskal-Wallis test: $\mathrm{P}=0.0023$ ) with numbers between 0 and 11 species per sampling location (Tab. 1, Fig. S1). The two most abundant fish species were the three-spined stickleback Gasterosteus aculeatus and the nine-spined stickleback Pungitius pungitius.

\section{Species composition, taxonomic diversity and abundance ( $\alpha$ - and $\gamma$-diversity)}

In total, 5,703 adult Coleoptera individuals were collected, belonging to 10 families, 42 genera and 108 taxa (Tab. S2). In average, $46.0 \pm 34.8$ individuals were caught per sampling location. The mean taxa richness was 13.6 \pm 6.0 taxa over all study sites. The Dytiscidae represented the most diverse and abundant family, followed by Hydrophilidae and Haliplidae (Figs. 2 and S2).

The taxon accumulation curve over all 124 samples almost reached an asymptote, which indicates nearly exhaustive exploration of the regional pool of species that was accessible with the applied method (Fig. 3). For sampling locations, the number of beetle taxa was positively correlated to the number of individuals (linear correlation: Pearson's $r=0.773, \mathrm{P}<0.0001$ ).

In opposite to the number of taxa (Kruskal-Wallis test:
$\mathrm{P}=0.063$ ), the number of individuals at the sampling locations differed significantly between the study sites (Kruskal-Wallis test: $\mathrm{P}=0.019$ ). However, Simpson's diversity indices of the sampling locations showed significant differences between the study sites (KruskalWallis test: $\mathrm{P}=0.011$ ), ranging from $0.76 \pm 0.12$ (study site 1) to $0.86 \pm 0.05$ (study site 2). Likewise, the study sites differed regarding Shannon's diversity indices (one-way ANOVA: $\mathrm{P}=0.002, \mathrm{~F}=3.799$, $\mathrm{df}=6$ ). Again, study site 1 showed the lowest mean Shannon index values (1.88 \pm 0.47$)$, while study site 2 showed the highest (2.36 \pm 0.38$)$. The evenness was similar between the study sites (one-way ANOVA: $\mathrm{P}=0.231, \mathrm{~F}=1.417, \mathrm{df}=6$ ) with an average of $0.68 \pm 0.13$ (Tab. 3).

The 'main taxa' were comprised by seven taxa with Hydroporus palustris being the only dominant species ( $14.47 \%$ of total individuals). The other six main taxa were considered as subdominant (Hygrotus inaequalis, Hyphydrus ovatus, Noterus crassicornis, Anacaena limbata, Helophorus aquaticus/aequalis, Haliplus ruficollis). The remaining 101 'companion taxa' were divided into recedent (14 taxa) and subrecedent (87 taxa). Only a single individual was caught from 18 taxa, respectively. See Fig. 3 for the rank abundance curve.

The dominance structure of the single study sites differed to some extent (Tab. S2). The overall dominant H. palustris was the most abundant species in four out of seven study sites (with a maximal relative abundance of
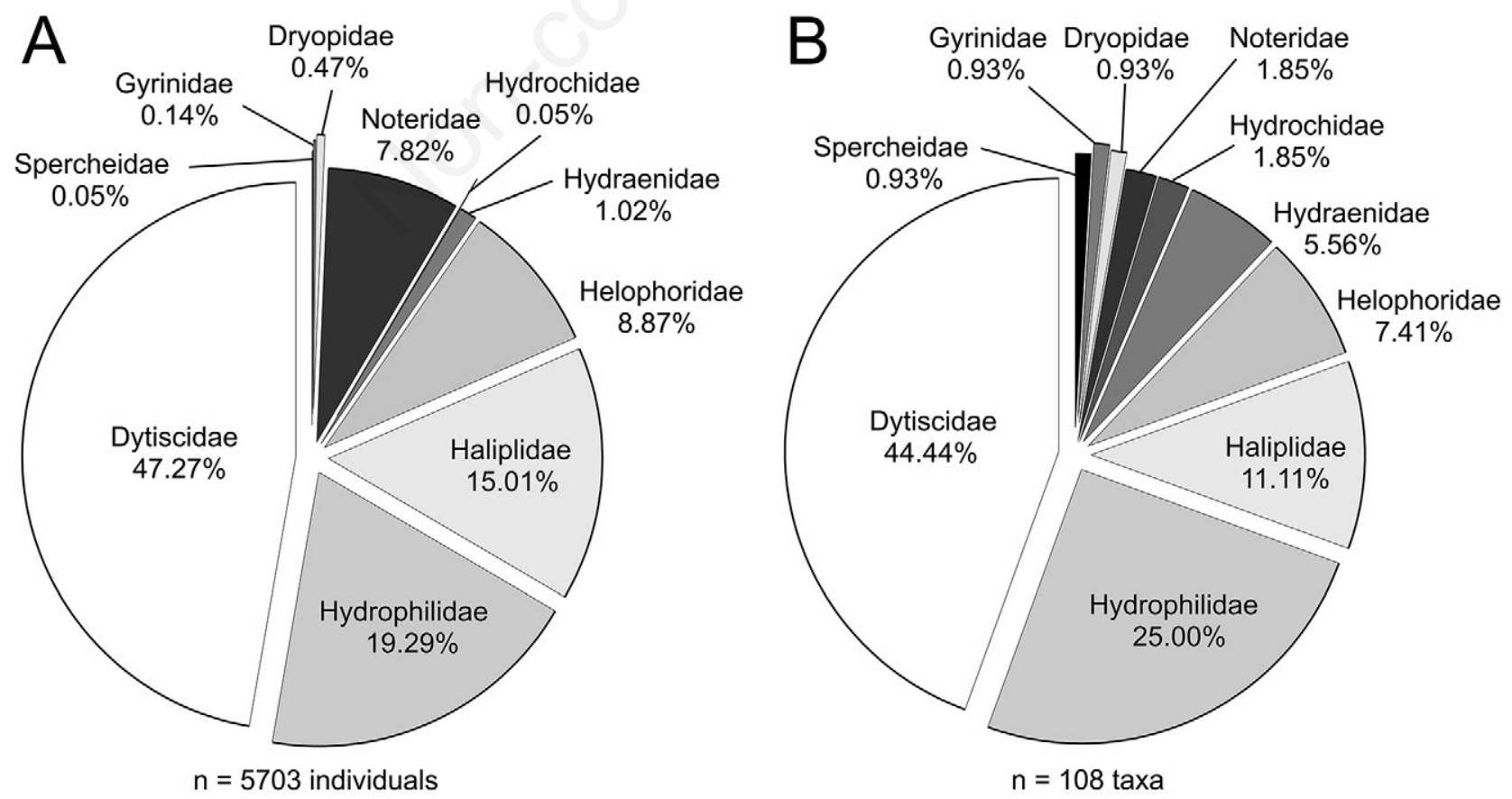

Fig. 2. Percentage of individuals (A) and taxa (B) to the detected beetle families. 
$22.97 \%$ at study site 6 and minimum of $4.03 \%$ at study site 5). In contrast, at study site 1 , the species pair Helophorus flavipes/obscurus dominated with a relative abundance of $21.12 \%$. However, $H$. flavipes/obscurus was considerably less abundant at other study sites (relative abundance, $0.23 \pm 0.42 \%$ ) and was even absent in study sites 3-5.

\section{Faunal comparison ( $\beta$-diversity)}

The species similarity in the pairwise comparison of the study sites ranged between 46.0 and 61.3 based on the Jaccard index (presence/absence of taxa). Regarding the Sørensen index, which weights abundant taxa stronger
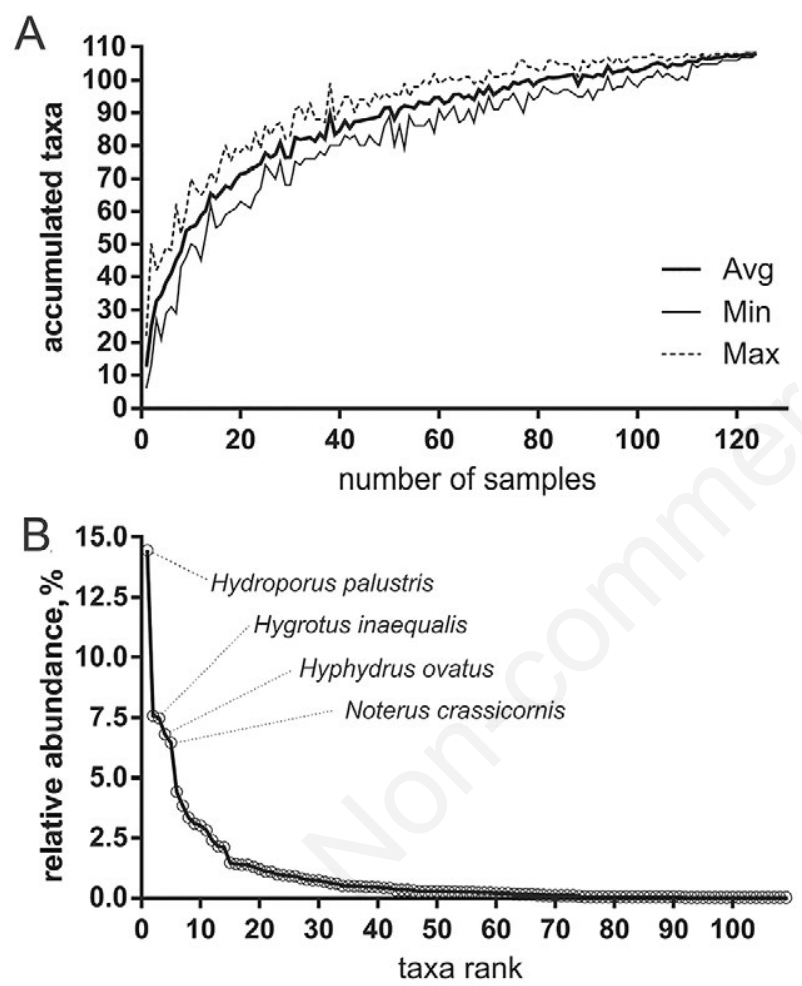

Fig. 3. Accumulation curve of beetle taxa based on the number of samples taken (A). Rank abundance curve including all taxa recorded. Most abundant species indicated (B). $n=5703$ individuals. than the Jaccard index, the values showed a minimum of 62.4 and a maximum of 73.7. The pairwise comparison of the dominance identities of the study sites by using the Renkonen index resulted in values between 40.0 and 69.1. Values of the Wainstein index (multiplication of indices by Jaccard and Renkonen) differed between 18.5 and 39.6 (Tab. S3).

\section{Morphological and ecological traits}

The 'hydradephagan' subset of beetles was analyzed according to its flight ability (Fig. 4). The percentage of flightless taxa was mainly attributable to the three species Hyphydrus ovatus, Noterus crassicornis and Agabus undulatus. 'Variable species' that often show reduced flight ability (Kehl and Dettner, 2007) (Fig. 4) include Hydroporus palustris, Hygrotus inaequalis and Haliplus ruficollis. All dominant and subdominant hydradephagan taxa (see species abundance) were either flightless or showed reduced flight ability in at least a proportion of individuals. The pattern was similar between the study sites (Fig. S2).

Regarding the traits 'locomotion mode', 'feeding group' and 'trophic level', data were weighted by the relative abundance and maximal body size and thus represents estimations about the proportion of the related trait modalities within the beetle biomass recorded. The most important locomotion modes were swimming and crawling (Fig. 5).

Predation was the most widely used feeding type within the beetle community (Fig. 5b). Accordingly, carnivory is the dominant trophical level (Fig. 5c). Patterns were similar between the study sites (Fig. S2).

\section{Relationship between environmental factors and beetle community}

In order to identify the main factors that contribute most to the variation of environmental data a RDA-based variance partitioning was performed including both the environmental and taxa abundance data. The total explained variance of beetle community composition was $18.71 \%$. The partial RDAs yielded that water chemistry (C) contributed mostly to the explained variance $(6.33 \%)$, followed by ditch morphology (M, 4.81\%), time (T,

Tab. 3. Parameters of $\alpha$-diversity at the study sites and $\gamma$-diversity at the whole study region.

\begin{tabular}{|c|c|c|c|c|c|c|c|c|}
\hline \multirow[t]{2}{*}{ Parameter } & \multicolumn{7}{|c|}{ Study $\operatorname{site}(\boldsymbol{\alpha}$-diversity) } & \multirow[t]{2}{*}{ Total $(\gamma$-diversity) } \\
\hline & 1 & 2 & 3 & 4 & 5 & 6 & 7 & \\
\hline Simpson index $(1-D)$ & 0.90 & 0.95 & 0.90 & 0.92 & 0.92 & 0.87 & 0.94 & 0.94 \\
\hline Shannon index $\left(H^{\prime}\right)$ & 2.79 & 3.44 & 2.88 & 3.10 & 3.02 & 2.51 & 3.12 & 3.37 \\
\hline Evenness $(E)$ & 0.32 & 0.44 & 0.33 & 0.38 & 0.40 & 0.28 & 0.50 & 0.30 \\
\hline
\end{tabular}


$2.97 \%$ ) and presence of fish (F, 2.69\%). The shared variance between all groups of environmental factors was $1.91 \%$. If only taxa with reduced flight ability (Hydradephaga assigned to categories 1 and 2a) were considered, the total explained variance reached $18.77 \%$, similar to the total data set of all taxa. Compared to the partial RDA on all taxa, the proportions of variance explained by ditch morphology (M, 4.77\%) and time (T, $2.43 \%$ ) were slightly reduced, whereas variance explained by water chemistry $(\mathrm{C}, 6.69 \%)$ and in particular the presence of fish (F, 3.83\%) increased.

Patterns within the beetle community related to sampling sites and environmental factors are displayed in Fig. 6. The result of the ANOVA like permutation test showed a significance of all canonical axes (eigenvalue $=0.442$, -ratio $=2.362, \mathrm{P}<0.001$ ) as well as of the first axis (eigenvalue $=0.152$, F-ratio $=7.309, \mathrm{P}<0.001$ ). Water temperature and $\mathrm{pH}$ were the major parameters contributing to RDA1, whereas the number of fish species was most influential to RDA2 together with electrical conductivity (Tab. S4). Taxa with the highest scores (absolute values) on RDA1 were Hydroporus palustris, Hydrobius fuscipes complex, Haliplus s. str. spec. and Noterus crassicornis (Tab. S4). Highest scores on RDA2

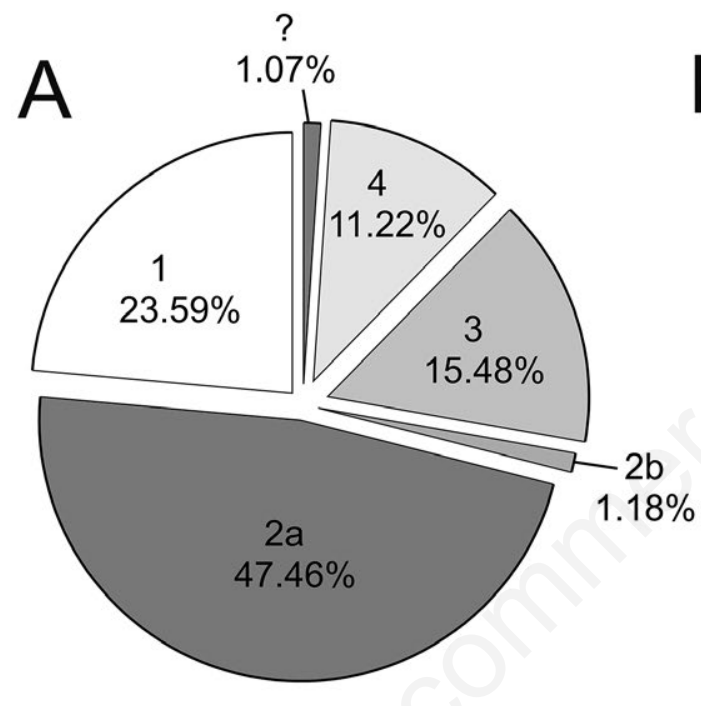

$\mathrm{n}=3565$ individuals
B

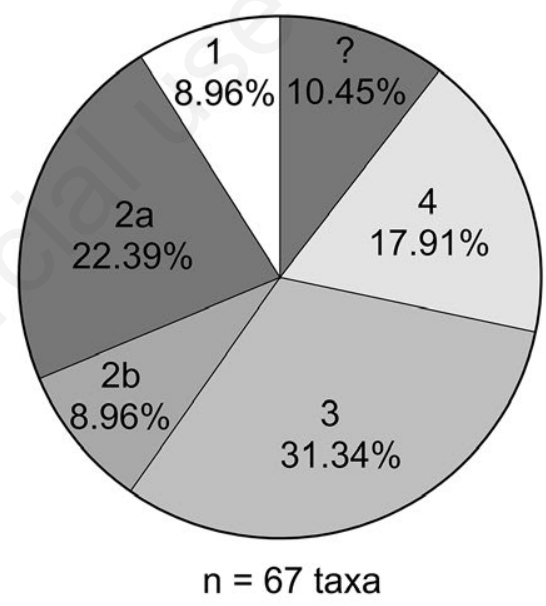

Fig. 4. Percentage of individuals (A) and taxa (B) to the categories flight ability (1, flightless; 2a, variable; $2 b$, presumably variable; 3 , flier; 4, good flier; ?, unknown) of the 'hydradephagan' data subset.
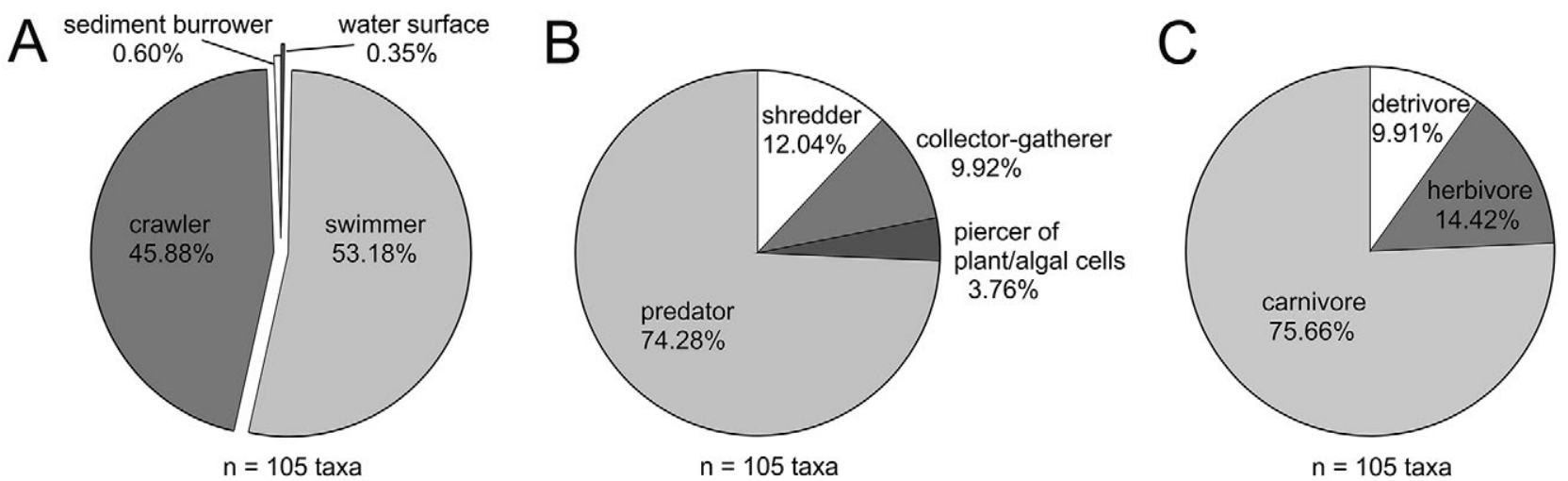

Fig. 5. Percentage of locomotion mode (A), feeding type (B) and trophic level (C) on the community of aquatic Coleoptera. Underlying data was weighted by taxon abundance and individual body length to show trait percentages of the approximated beetle biomass. 
were shown by Helophorus aquaticus/aequalis, Anacaena limbata and Hygrotus inaequalis (Tab. S4). Most taxa were located at the center of the ordination plot (Fig. 6), which indicates an indifferent relation to the first two RDA axes. The dominant taxon Hydroporus palustris was negatively correlated to the presence of fish and width of the ditch whereas Helophorus aquaticus/aequalis showed a positive correlation to the thickness of the sediment layer and electrical conductivity. The individual sampling locations clustered for some extend according to their study site assignment, for example sampling locations of site 5 (predominantly plotted on the right half), site 6 (exclusively plotted on the top half) and site 7 (predominantly plotted on the lower left quarter). In contrast, sampling locations of site 1, 3 and 4 did not show a defined pattern. This indicates that, e.g., sampling locations at study site 5 were influenced by higher $\mathrm{pH}$ values than study site 2 (Tab. 1).

\section{Endangerment and rarity}

The proportion of threatened species (related to Germany) was 13.0\% (58 individuals, 13 species) (Fig. 7). This includes two species of the category 'endangered' (Hydroporus scalesianus, Haliplus furcatus), three 'vulnerable' species (Agabus unguicularis, Graptodytes bilineatus, Rhantus bistriatus) and 8 species categorized as 'near threatened'. The data situation about endangerment is deficient for the two species, Enochrus fuscipennis and Hydroporus figuratus. However, also the Red List data regarding $H$. figuratus are deficient because this species was separated from Hydroporus dorsalis only recently (Bergsten et al., 2012, 2013).

In total, $18.4 \%$ of the recorded species were categorized as 'rare' (60 individuals, 15 species) or 'very rare' (9 individuals, 3 species). Very rare species comprised Hydaticus continentalis, Rhantus bistriatus

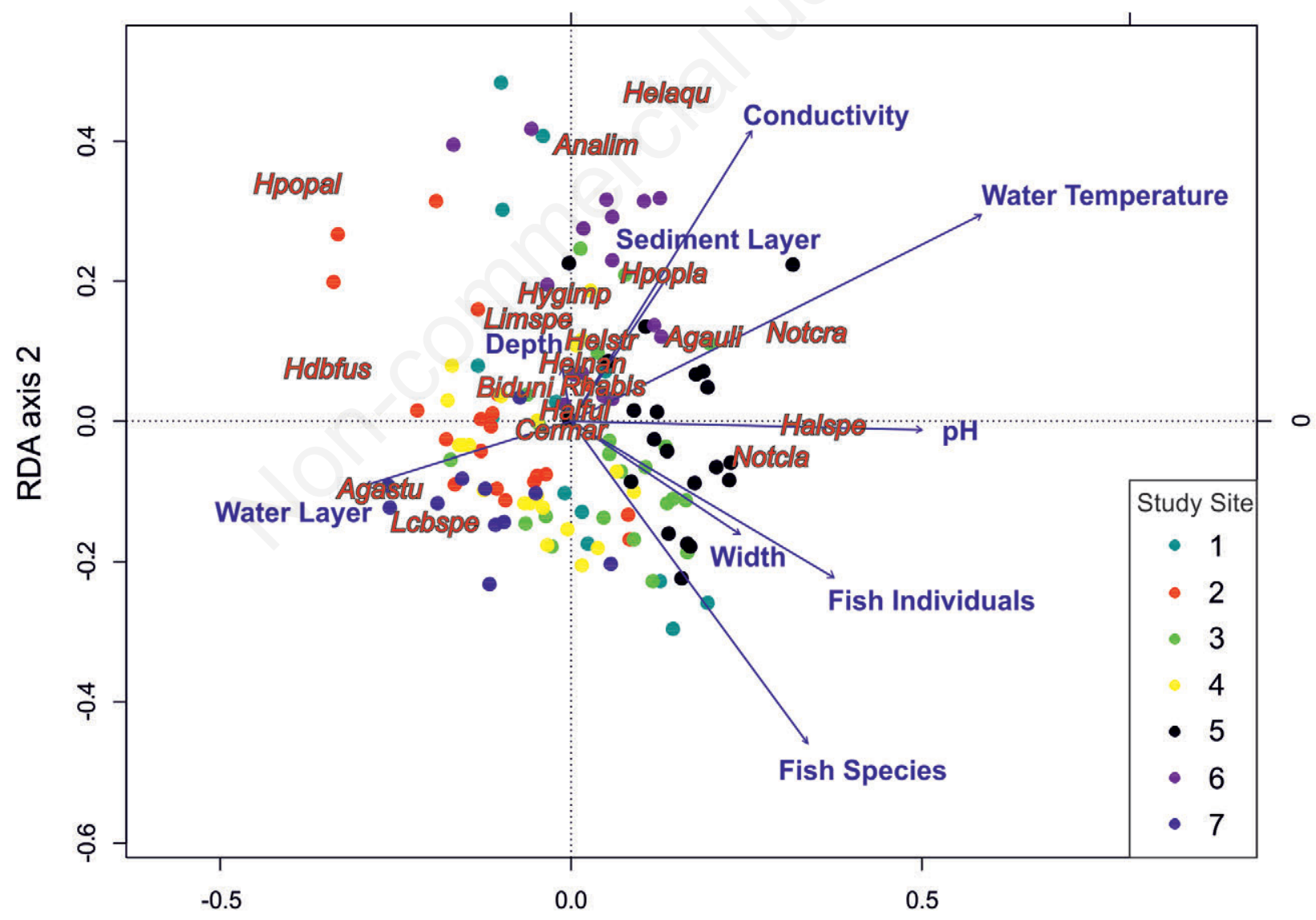

RDA axis 1

Fig. 6. Ordination plot of partial redundancy analysis (RDA) considering 'time' as covariate. Analyzed data included taxa abundance per sampling location and environmental parameters. Axis 1: eigenvalue 0.152, Axis 2: eigenvalue 0.092. Variance ('inertia'): total 2.893, constrained 0.442 , conditional (covariate 'time') 0.099. Due to clarity reasons, only 19 taxa were plotted (see Fig. S3 with all taxa plotted, Tab. S4 for taxa abbreviations for RDA scores). 
and Haliplus furcatus. The remaining taxa were either 'moderately common', 'common' or 'abundant' (Fig. 7).

The comparison of the seven study locations showed that all taxa of the categories 'endangered' and 'very rare' were found at the study sites 2, 3, 4 and 5 (Fig. S2) that might be biased by the higher numbers of sampling locations within these study sites (Tab. 1).

\section{DISCUSSION}

\section{High species richness in agricultural ditches}

Compared with the number of aquatic beetle species within the considered families known for Germany (Spitzenberg et al., 2016), around one third (32.5\%) has

A

vulnerable near threatened

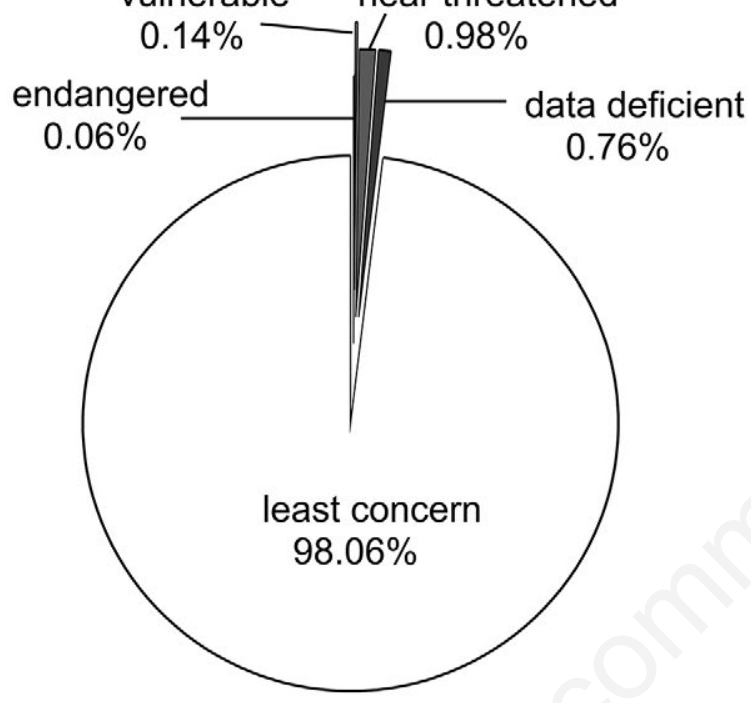

$\mathrm{n}=4849$ individuals

B vulnerable

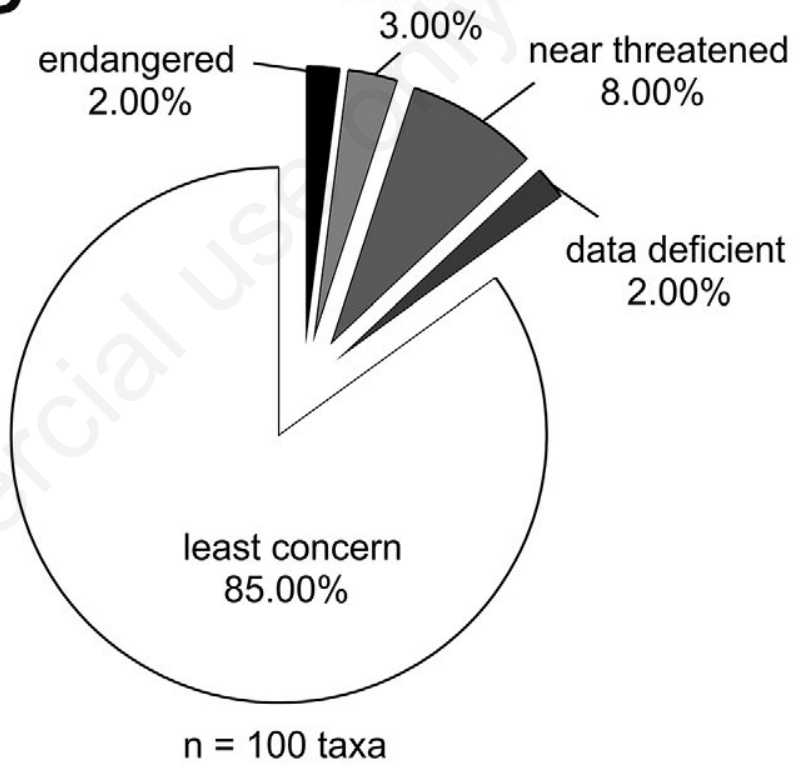

C

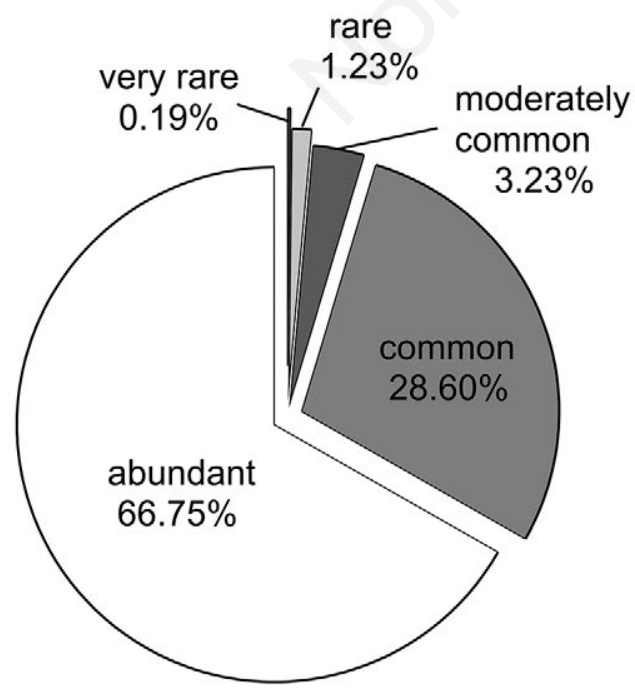

$\mathrm{n}=5136$ individuals
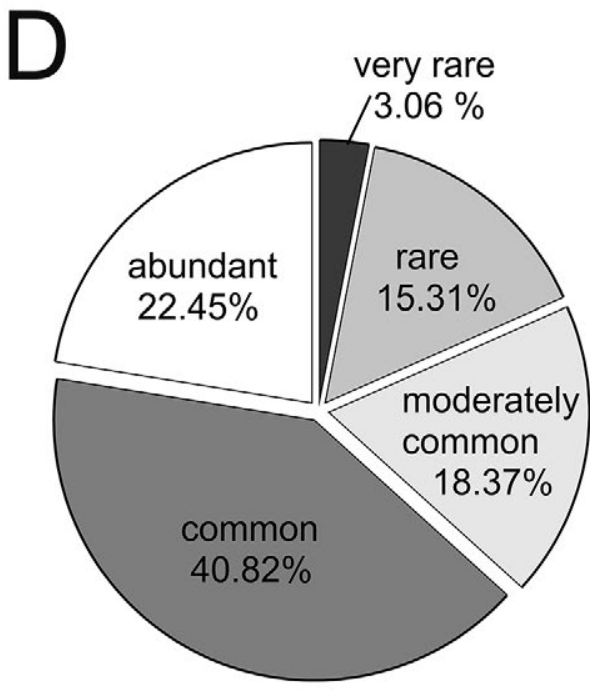

$\mathrm{n}=102$ taxa

Fig. 7. Percentage of individuals and taxa to the categories of endangerment (A, B) and rarity (C, D) with relation to Germany. 
been collected in the study area. On a more regional scale, almost half $(47.3 \%)$ of the species known for the federal state of Brandenburg (Braasch et al., 2000) were detected. Braasch et al. (2000) further valuated the species according to their habitat preferences. Thus, the number of recorded species reached $88.1 \%$ of the number of species known to occur in agricultural ditches in the region. According to the short sampling period between end of March and beginning of August and the spatial framework of the present study (124 sampling locations within an approximately $500 \mathrm{~km}^{2}$ area), these percentages should be considered as high and the used methodology as effective. Therefore, the range of beetle species identified here, seems almost be exhaustive for that habitat type in the region, which is further indicated by the accumulation curve (Fig. 3A). The high biodiversity value ( $\alpha$ - and $\gamma$-diversity) of the studied ditches is also reflected by relatively high values of diversity indices.

These results showed higher aquatic beetle richness than other field studies in different European regions. For example, Verdonschot et al. (2011) recorded 29 taxa of the considered families ( 9 ditches in the Netherlands) and Hill et al. (2016) found 48 taxa (excluding larvae and beetles of other families; 12 ditches in the UK). A plausible explanation for the differences might be the comparably lower number of ditches studied. However, Painter (1999) recorded 91 aquatic beetle taxa (excluding three Elmidae species) within 12 ditches in two fens in the UK that accounts for a comparable taxonomic diversity as in the present study.

Interestingly, other aquatic habitat types, like e.g. farmland ponds in Ireland (76 species, 54 ponds, Gioria et al., 2010), wetland ponds in Pennsylvania (USA, 66 species [exluding larvae and beetles of other families], 18 ponds, Fairchild et al., 2000) and clay- and gravel-pits (125 species, 44 water bodies, Pakulnicka 2008) as well as sites of standing waters of various types within a river valley in Poland (112 species, 89 water bodies, Pakulnicka et al., 2016) revealed similar beetle biodiversity like the present study in northeastern German ditches.

Surprisingly, a subset of species sampled was not known to show affinity for agricultural ditches according to Braasch et al. (2000). For example, Haliplus fluviatilis recorded with 5 specimens from two different study sites prefers lotic waters but may also occur in lakes (van Vondel and Dettner, 1997; Braasch et al., 2000). Possibly, the proximity to lotic waters like the river Havel and bigger canals as well as to smaller streams may lead to rare appearance of this species in the ditches. Other species like Haliplus furcatus, Haliplus heydeni, Bidessus unistriatus, Hydroporus scalesianus, Ilybius ater or Enochrus fuscipennis are regularly known from moors and fens (Nilsson and Holmen, 1995; van Vondel and Dettner, 1997; Braasch et al., 2000; Hebauer and
Klausnitzer, 2000). These species were found partially in considerable abundances throughout the whole study area. This possibly indicates that a substantial amount of the studied ditches has to be seen as remnant structures of a former moor and fenland that was converted into agricultural crop or grassland by drainage. Thus, characteristics of former wetland types which now are turned into drained areas may still influence the ditches which in turn provide niches for more or less specialized species. Another possible explanation for the occurrence of species not regularly found in ditches could be that these artificial water bodies are used as stepping stones or temporary habitats within the agrarian landscape (Duelli and Obrist, 2003).

Although the studied sampling sites were all assigned to the same habitat type, there were significant differences in the measured morphological and physico-chemical parameters. This accounts for a mosaic of slightly different ditches or ditch segments that may also enhance biodiversity due to high within-habitat heterogeneity (Stein et al., 2014).

\section{Dominance of taxa associated with eutrophic waters}

Regarding the taxonomic diversity, almost half of all individuals and taxa sampled belong to the family Dytiscidae (predaceous diving beetles), followed by Hydrophilidae (water scavenger beetles) and Haliplidae (water crawling beetles). The dominance of dytiscids within the aquatic beetle assemblages is common and not surprising, since many studies demonstrated this as well (Foster et al., 1992; Painter, 1999; Fairchild et al., 2000; Pakulnicka, 2008; Verdonschot et al., 2011; Pakulnicka et al., 2016). It also reflects the overall taxonomic diversity of aquatic beetles, since Dytiscidae is the most speciose family of this group of insects, both in Germany (Spitzenberg et al., 2016) and worldwide (Jäch and Balke, 2008). On the species level, the dominance structure of the assessed community showed a very typical pattern (Magurran and Henderson, 2003): despite being speciesrich, the investigated beetle assemblages were dominated by few very abundant and dominant main taxa accompanied by a large number of less abundant taxa. This was shown by the relatively steep decline of the rank abundance curve (Fig. 3B), indicating a relatively low evenness. These main taxa as Hydroporus palustris, Hygrotus inaequalis, Hyphydrus ovatus, Noterus crassicornis, Anacaena limbata, Helophorus aquaticus/aequalis and Haliplus ruficollis were predominantly considered as eurytopic as well as detritophilous and iliophilous (Braasch et al., 2000). In fact, species associated with clear oligotrophic waters or water bodies with low succession stages (pioneer species) were not or rarely recorded throughout the study. This clearly points to the eutrophic character of the ditches 
studied. Drainage ditches within agricultural landscapes are exposed to nutrient run-offs from the surrounding areas that clearly influence species composition (Janse and Van Puijenbroek, 1998; Riis and Sand-Jensen, 2001) but not necessarily impair local taxonomic richness (Pakulnicka, 2008; Rosset et al., 2014).

\section{Moderate turnover of taxa between the study sites}

The faunal comparison between the seven study sites ( $\beta$-diversity) revealed some differences based on the taxa identities (shown by Jaccard and Sørensen indices). Jaccard indices showed that the study sites shared approximately half of their species inventory. This was relatively homogenous between all pairs of study sites. Likewise, Sørensen indices showed similar values between pairs of sites. The fact that values of Sørensen index were higher compared to values of Jaccard index can be explained by the presence of abundant taxa that are found at each of the sites. These are more influential to the Sørensen than to the Jaccard index (Jost et al., 2011). The risk that $\beta$-diversity measures were impaired by an artifact due to the undersampling of rare species was reduced by the use of abundance data rather than presence-absence data (Barwell et al., 2015). However, pairs of study sites exhibiting the highest values of taxa similarity (e.g., study sites 1 and 5) did not necessarily show the most similar dominance identities (Renkonen and Wainstein indices). This indicates abundance differences between the sites even regarding the more dominant taxa, as demonstrated for Hydroporus palustris and Helophorus flavipes/obscurus. Taken together, the faunal comparison of the study sites indicates a moderate turnover. However, all beetle assemblages at the study sites should be considered as part of the same faunal continuum. This also was supported by the applied ordination and may not be surprising because of the geographical proximity of the study sites.

\section{Individuals with reduced flight ability were dominant}

Species occurrence within a certain habitat depends on its ability and strategy to disperse (Bowler and Benton, 2005). Aquatic beetles move between habitats most effectively by flying (Arribas et al., 2011; Bilton, 2014). However, flight ability is developed differently, both between and within species (Jackson, 1973; Kehl and Dettner, 2007; Iversen et al., 2017). The investigated beetle community (at least the analyzed hydradephagan subset) was dominated by individuals either flightless or with reduced flight ability (Kehl and Dettner, 2007) of only few dominant species. Taxa that were recorded only by few individuals were present both among less (e.g., Ilybius fenestratus, Hydaticus transversalis) and highly mobile species (e.g., Haliplus obliquus, Hydroporus planus). Most likely, the connectivity of the investigated drainage ditch networks to different water systems such as the river Havel, which shows lake-like expansions in the region (Fig. 1), allows a dispersal of aquatic beetles by water. This also could explain the widespread presence of flightless and variable species. It is also supported by the finding, that both swimming and crawling were the most preferential underwater locomotion modes facilitating the dispersal within the study area. Kehl and Dettner (2007) linked the flight ability with habitat stability. It appears that stable habitats harbor more species unable to fly than unstable habitats. Drainage ditches may exhibit a certain degree of instability due to periodic maintenance measures, dehydration of ditch segments or other seasonal physico-chemical changes. Moreover, the change of physico-chemical conditions in the agricultural ditches sometimes takes place within a few hours, often to a considerable extant. However, the fact that less mobile species dominate on the individual level indicates a certain habitat tradition or might be due to a different reproduction strategy. In addition, seasonal effects on dispersal rates might influence the abundances of mobile species (Miguélez and Valladares, 2008; Iversen et al., 2017).

\section{Beetles are mainly integrated as carnivores in the food web of ditches}

The analysis of feeding types and trophic levels among the aquatic beetle community in ditches underpins their general role as important predators within freshwater food webs (Batzer and Wissinger, 1996). This was mainly attributable to the dominance of Dytiscidae. This family consists solely of carnivorous species and large dytiscids are among the top insect predators in fish free aquatic habitats (Culler et al., 2014; Miller and Bergsten, 2016). In addition, species of Noteridae and Gyrinidae as well as larvae of Hydrophilidae are carnivorous (Holmen, 1987; van Vondel and Dettner, 1997; Hebauer and Klausnitzer, 2000). Thus, aquatic Coleoptera contribute to structure invertebrate life in agricultural drainage ditches, both by direct predation and non-consumptive effects (Cobbaert et al., 2010; Culler et al., 2014). Their role as herbivores and detrivores is of subordinate importance. In turn, aquatic beetles may itself serve as resources for taxa of higher trophic levels such as fish or Odonata larvae (Larson, 1990) or water and wading birds.

\section{Measured environmental parameters weakly influenced beetle composition}

Relationships between environmental factors and beetle composition in the ditches were investigated by direct ordination (RDA). RDA-based variance partitioning on the total beetle community composition 
revealed an overall explained variance of $18.71 \%$. In general, the results indicate that the community composition of aquatic Coleoptera in the ditches is either not structured by one single main environmental factor, or this single main factor was missing in the set of variables measured. The overall percentages of explained variance appeared to be in the same range or slightly lower compared to results of similar studies (Gioria et al., 2010; Larsen et al., 2012; Ieromina et al., 2016a, 2016b). In fact, earlier studies pointed out the influence of additional abiotic (e.g., nutrients, pesticides) and biotic (e.g., submerged vegetation) parameters as more or less important predictors of aquatic community composition (Hinojosa-Garro et al., 2010; Verdonschot et al., 2012a; Pakulnicka et al., 2015b; Whatley et al., 2015; Ieromina et al., 2016a, 2016b). For example, submerged vegetation increases structural complexity that supports biodiversity (Scheffer et al., 1984; Hinojosa-Garro et al., 2010; Hansen et al., 2011; Whatley et al., 2014) although Verdonschot et al. (2012a) found no relation between microhabitat complexity and macroinvertebrate assemblages in ditches. Apart from this, variance partitioning in the present study further showed that abiotic factors as water chemistry and ditch morphology were more influential to beetle composition than the presence of fish. However, both the abundance and taxonomical diversity of fish showed a negative correlation with the abundance of particular beetle species such as the dominant Hydroporus palustris. Earlier studies found strong effects of fish occurrence on beetle abundance and species richness (Foster, 1991; Fairchild et al., 2000). Obviously, fish act as important predators for aquatic beetles that can reduce abundances. Furthermore, aquatic beetles actively select for habitats with no or low numbers of fish (Binckley and Resetarits, 2005; Brodin et al., 2006). Interestingly, when only the subset of taxa with reduced flight ability was analyzed by RDA-based variance partitioning, the percentage of variance in abundance explained by the presence of fish increased, pointing to a higher sensitivity of flightless than mobile beetles to fish.

\section{Drainage ditches as habitat for threatened and rare species}

A set of noteworthy Coleoptera species could be found in the studied agricultural ditches in the region. In total, $13.0 \%$ of threatened species (related to Germany) were recorded. Furthermore, $18.4 \%$ rare and very rare species were found. The federal state of Brandenburg in which this study was conducted also seems to have a high responsibility for species as Colymbetes striatus, Hydaticus continentalis or Rhantus bistriatus, which are nationally threatened and experienced severe losses (Hendrich and Müller, 2017) but could be recorded in drainage ditches in the present study.

Globally, freshwater biodiversity is under threat (Dudgeon et al., 2006). In general, conservation effort mainly concentrated on natural and larger freshwater ecosystems (Clarke, 2015). In Germany and other countries, the loss and degradation of small water bodies has to be considered as one of the major threats to freshwater biodiversity including aquatic beetles (Dudgeon et al., 2006; Spitzenberg et al., 2016). In particular, surface drainage ditches in the agrarian landscapes are threatened by replacement of subsurface piping (Herzon and Helenius, 2008).

\section{CONCLUSIONS}

The high biodiversity value of agricultural drainage ditches as surrogate habitat here demonstrated for aquatic beetles supports findings of other studies (Painter, 1999; Armitage et al., 2003; Williams et al., 2003; Davies et al., 2008a, 2008b; Verdonschot et al., 2011; Hill et al., 2016). Thus, it further addresses the necessity to increasingly include anthropogenic habitats like ditches in conservation management that is not yet articulated by formal legislative protection. Especially in a context of a hyper exploited landscape where natural systems are rare, anthropogenic habitats may serve as complementary systems, provided that their management considers the needs of biodiversity.

\section{ACKNOWLEDGMENTS}

We are grateful to 'Wasser- und Bodenverband, Großer Havelländischer Hauptkanal - Havelkanal Havelseen, Nauen' for support and the possibility to gain access to all ditches within the study area. We thank Jens Gerlach (Naturkundemuseum Potsdam) for technical assistance. The database on traits and functional parameters of lentic Macroinvertebrates was generously provided by Ralf C. M. Verdonschot (Wageningen Environmental Research, Alterra, The Netherlands).

\section{REFERENCES}

Angus R, 1992. Insecta: Coleoptera: Hydrophilidae: Helophorinae, p. 144 In: Schwoerbel J and P Zwick (eds.), Süßwasserfauna von Mitteleuropa, Stuttgart, Jena, New York: Gustav Fischer Verlag.

Armitage PD, Szoszkiewicz K, Blackburn JH, Nesbitt I, 2003. Ditch communities: A major contributor to floodplain biodiversity. Aquat. Conserv. 13:165-185.

Arribas P, Velasco J, Abellán P, Sánchez-Fernández D, Andújar C, Calosi P, Millán A, Ribera I, Bilton DT, 2011. Dispersal ability rather than ecological tolerance drives differences in range size between lentic and lotic water beetles 
(Coleoptera: Hydrophilidae). J. Biogeogr. 39:984-994.

Barton PS, Cunningham SA, Manning AD, Gibb H, Lindenmayer DB, Didham RK, 2013. The spatial scaling of beta diversity. Glob. Ecol. Biogeogr. 22:639-647.

Barwell LJ, Isaac NJB, Kunin WE, 2015. Measuring $\beta$-diversity with species abundance data. J. Anim. Ecol. 84:1112-1122.

Batzer DP, Wissinger SA, 1996. Ecology of insect communities in Nontidal Wetlands. Annu. Rev. Entomol. 41:75-100.

Bergsten J, Brilmyer G, Crampton-Platt A, Nilsson AN, 2012. Sympatry and colour variation disguised well-differentiated sister species: Suphrodytes revised with integrative taxonomy including $5 \mathrm{kbp}$ of housekeeping genes (Coleoptera: Dytiscidae). DNA Barcodes 1:1-18.

Bergsten J, Nilsson AN, Ronquist F, 2013. Bayesian tests of topology hypotheses with an example from diving beetles. Syst. Biol. 62:660-673.

Bilton DT, 2014. Dispersal in Dytiscidae, p. 387-407 In: D. Yee (ed.), Ecology, systematics, and the natural history of predaceous diving beetles (Coleoptera: Dytiscidae). Springer, Dordrecht.

Binckley CA, Resetarits WJ, 2005. Habitat selection determines abundance, richness and species composition of beetles in aquatic communities. Biol. Lett. 1:370-374.

Bowler DE, Benton TG, 2005. Causes and consequences of animal dispersal strategies: relating individual behaviour to spatial dynamics. Biol. Rev. 80:205-225.

Braak CJF ter, Šmilauer P, 2002. CANOCO Reference Manual and CanoDraw for Windows User's Guide: Software for Canonical Community Ordination (Version 4.5). Microcomputer Power, Ithaca: $500 \mathrm{pp}$.

Braasch D, Hendrich L, Balke M, 2000. [Rote Liste und Artenliste der Wasserkäfer des Landes Brandenburg (Coleoptera: Hydradephaga, Hydrophiloidea part., Dryoopoidea part. und Hydraenidae)].[Article in German]. Naturschutz und Landschaftspfl. Brand. 9:1-36.

Briers RA, Biggs J, 2005. Spatial patterns in pond invertebrate communities: Separating environmental and distance effects. Aquat. Conserv. 15:549-557.

Brodin T, Johansson F, Bergsten J, 2006. Predator related oviposition site selection of aquatic beetles (Hydroporus spp.) and effects on offspring life-history. Freshwater Biol. 51:1277-1285.

Clarke SJ, 2015. Conserving freshwater biodiversity: The value, status and management of high quality ditch systems. J. Nat. Conserv. 24:93-100.

Cobbaert D, Bayley SE, Greter JL, 2010. Effects of a top invertebrate predator (Dytiscus alaskanus; Coleoptera: Dytiscidae) on fishless pond ecosystems. Hydrobiologia 644:103-114.

Culler LE, Ohba S, Crumrine P, 2014. Predator-prey interactions of Dytiscids, p. 363-386 In: D. Yee (ed.), Ecology, systematics, and the natural history of predaceous diving beetles (Coleoptera: Dytiscidae). Springer, Dordrecht.

Davies B, Biggs J, Williams P, Whitfield M, Nicolet P, Sear D, Bray S, Maund S, 2008a. Comparative biodiversity of aquatic habitats in the European agricultural landscape. Agric. Ecosyst. Environ. 125:1-8.

Davies BR, Biggs J, Williams PJ, Lee JT, Thompson S, 2008 b. A comparison of the catchment sizes of rivers, streams, ponds, ditches and lakes: Implications for protecting aquatic biodiversity in an agricultural landscape. Hydrobiologia 597:7-17.

Drozd P, Novotny V, 2010. AccuCurve. Version 1.0. Available from: https://prf.osu.cz/kbe/8072/ecological-software/

Dudgeon D, Arthington AH, Gessner MO, Kawabata Z-I, Knowler DJ, Lévêque C, Naiman RJ, Prieur-Richard A-H, Soto D, Stiassny MLJ, Sullivan CA, 2006. Freshwater biodiversity: importance, threats, status and conservation challenges. Biol. Rev. 81:163.

Duelli P, Obrist MK, 2003. Regional biodiversity in an agricultural landscape: the contribution of seminatural habitat islands. Basic Appl. Ecol. 4:129-138.

Engelmann H-D, 1978. [Zur Dominanzklassifizierung von Bodenarthropoden].[Article in German]. Pedobiologica 18:378-380.

Fairchild GW, Faulds a M, Matta JF, 2000. Beetle assemblages in ponds:effects of habitat and site age. Freshw. Biol. 44:523-534.

Fischer J, Lindenmayer DB, 2007. Landscape modification and habitat fragmentation: a synthesis. Glob. Ecol. Biogeogr. 16:265-280

Fossen EI, Ekrem T, Nilsson AN, Bergsten J, 2016. Species delimitation in northern European water scavenger beetles of the genus Hydrobius (Coleoptera, Hydrophilidae). Zookeys 2016:71-120.

Foster GN, 1991. Aquatic beetle population changes associated with recreating a trout fishery by liming a lake catchment. Arch. Hydrobiol. 122:313-322.

Foster GN, Nelson BH, Bilton DT, Lott DA, Merritt R, Weyl RS, Eyre MD, 1992. A classification and evaluation of Irish water beetle assemblages. Aquat. Conserv. 2:185-208.

Gerrish N, Bristow JM, 1979. Macroinvertebrate associations with aquatic macrophytes and artificial substrates. J. Great Lakes Res. 5:69-72.

Gioria M, Schaffers A, Bacaro G, Feehan J, 2010. The conservation value of farmland ponds: Predicting water beetle assemblages using vascular plants as a surrogate group. Biol. Conserv. 143:1125-1133.

Guareschi S, Abellán P, Laini A, Green AJ, Sánchez-Zapata JA, Velasco J, Millán A, 2015. Cross-taxon congruence in wetlands: assessing the value of waterbirds as surrogates of macroinvertebrate biodiversity in Mediterranean Ramsar sites. Ecol. Indic. 49:204-215.

Hammer Ø, Harper DAT, Ryan PD, 2001. PAST: Paleontological Statistics Software Package for Education and Data Analysis. Palaeontol. Electron. 4:1-9.

Hansen JP, Wikström SA, Axemar H, Kautsky L, 2011. Distribution differences and active habitat choices of invertebrates between macrophytes of different morphological complexity. Aquat. Ecol. 45:11-22.

Hebauer F, Klausnitzer B, 2000. Insecta: Coleoptera: Hydrophiloidea: Georissidae, Spercheidae, Hydrochidae, Hydrophilidae (exkl. Helophorus), p. 134 In: J. Schwoerbek and P. Zwick (eds.), Süßwasserfauna von Mitteleuropa. Gustav Fischer Verlag, Stuttgart.

Heino J, 2009. Biodiversity of aquatic insects: Spatial gradients and environmental correlates of assemblage-level measures at large scales. Freshw. Rev. 2:1-29.

Hendrich L, Müller R, 2017. [Rote Liste und Gesamtartenliste der Wasserkäfer von Berlin (Coleoptera: Hydradephaga, 
Hydrophiloidea part., Hydraenidae, Elmidae und Dryopidae)], p. 38. In: Der Landesbeauftragte für Naturschutz und Landschaftspflege / Senatsverwaltung für Umwelt, Verkehr und Klimaschutz (ed.), [Rote Listen der Gefährdeten Pflanzen, Pilze und Tiere von Berlin].[in German]. Senatsverwaltung für Umwelt, Verkehr und Klimaschutz, Berlin.

Herzon I, Helenius J, 2008. Agricultural drainage ditches, their biological importance and functioning. Biol. Conserv. 141:1171-1183.

Hill MJ, Chadd RP, Morris N, Swaine JD, Wood PJ, 2016. Aquatic macroinvertebrate biodiversity associated with artificial agricultural drainage ditches. Hydrobiologia 776:249-260.

Hinojosa-Garro D, Mason CF, Underwood GJC, 2010. Influence of macrophyte spatial architecture on periphyton and macroinvertebrate community structure in shallow water bodies under contrasting land management. Arch. Hydrobiol. 177:19-37.

Holmen M, 1987. The aquatic Adephaga (Coleoptera) of Fennoscandia and Denmark. I. Gyrinidae, Haliplidae, Hygrobiidae and Noteridae. Fauna Entomol. Scand. 20:1-168.

Ieromina O, Musters CJM, Bodegom PM, Peijnenburg WJGM, Vijver MG, 2016a. Trait modality distribution of aquatic macrofauna communities as explained by pesticides and water chemistry. Ecotoxicology 25:1170-1180.

Ieromina O, Peijnenburg WJGM, Musters CJM, Vijver MG, 2016b. The effect of pesticides on the composition of aquatic macrofauna communities in field ditches. Basic Appl. Ecol. 17:125-133.

Iversen LL, Rannap R, Briggs L, Sand-Jensen K, 2017. Timerestricted flight ability influences dispersal and colonization rates in a group of freshwater beetles. Ecol. Evol. 7:824-830.

Jäch MA, 1998. Annotated check list of aquatic and riparian/littoral beetle families of the world (Coleoptera), $\mathrm{p}$. 25-42. In: M.A. Jäch and L. Ji (eds.), Water beetles of China. Zoologisch-Botanische Gesellschaft and Wiener Coleopterologenverein, Vienna.

Jäch MA, Balke M, 2008. Global diversity of water beetles (Coleoptera) in freshwater. Hydrobiologia 595:419-442.

Jackson DJ, 1973. The influence of flight capacity on the distribution of aquatic Coleoptera in Fife and Kinross-shire. Entomol. Gaz. 24:247-293.

Janse JH, Puijenbroek PJTM Van, 1998. Effects of eutrophication in drainage ditches. Environ. Pollut. 102:547-552.

Jost L, Chao A, Chazdon RL, 2011. Compositional similarity and $\beta$ (beta) diversity, p. 66-84 In: A.E. Magurran and B.J. McGill (eds.), Biological diversity. Frontiers in measurement and assessment. Oxford University Press, Oxford.

Kehl S, Dettner K, 2007. [Flugfähigkeit der in Deutschland vorkommenden adephagen Wasserkäfer (Coleoptera , Hydradephaga)].[Article in German]. Entomol. Heute 19:141-161.

Larsen S, Mancini L, Pace G, Scalici M, Tancioni L, 2012. Weak concordance between fish and macroinvertebrates in Mediterranean streams. PLoS One 7:e51115.

Larson DJ, 1990. Odonate predation as a factor influencing dytiscid beetle distribution and community structure. Quaest. Entomol. 26:151-162.
Leslie AW, Smith RF, Ruppert DE, Bejleri K, Mcgrath JM, Needelman BA, Lamp WO, 2012. Environmental Factors structuring benthic macroinvertebrate communities of agricultural ditches in Maryland. Environ. Entomol. 41:802812.

Magurran AE, Henderson PA, 2003. Explaining the excess of rare species in natural species abundance distributions. Nature 422:714-716.

Menetrey N, Oertli B, Lachavanne JB, 2011. The CIEPT: a macroinvertebrate- based multimetric index for assessing the ecological quality of Swiss lowland ponds. Ecol. Indic 11:590-600.

Miguélez D, Valladares LF, 2008. Seasonal dispersal of water beetles (Coleoptera) in an agricultural landscape: A study using Moericke traps in northwest Spain. Ann. Soc. Entomol. Fr. 44:317-326.

Miller KB, Bergsten J, 2016. Diving beetles of the world. John Hopkins University Press, Baltimore: 320 pp.

Moroz MD, 1993. Ecological and zoogeographical characteristic of the Hydradephaga (Coleoptera, Adephaga) In the land reclamation canals of Belarus. Entomol. Rev. 72:321-325.

Morris EK, Caruso T, Buscot F, Fischer M, Hancock C, Maier TS, Meiners T, Müller C, Obermaier E, Prati D, Socher SA, Sonnemann I, Wäschke N, Wubet T, Wurst S, Rillig MC, 2014. Choosing and using diversity indices: Insights for ecological applications from the German Biodiversity Exploratories. Ecol. Evol. 4:3514-3524.

Mouillot D, Spatharis S, Reizopoulou S, Laugier T, Sabetta L, Basset A, Do Chi T, 2006. Alternatives to taxonomic-based approaches to assess changes in transitional water communities. Aquat. Conserv. 16:469-482.

Mühlenberg M, 1989.[Freilandökologie].[Book in German]. Ulmer, Stuttgart: $430 \mathrm{pp}$.

Nijboer RC, Verdonschot PFM, 2000. Taxonomic adjustment affects data analysis: an often forgotten error. Verh. Internat. Verein. Limnol. 27:2546-2549.

Nilsson AN, Holmen M, 1995. The aquatic Adephaga (Coleoptera) of Fennoscandia and Denmark. II. Dytiscidae. Fauna Entomol. Scand. 32:1-192.

Oksanen J, Blanchet FG, Kindt R, Legendre P, Minchin PR, O'Hara RB, Simpson GL, Solymos P, Stevens MHH, Wagner H, 2016. Vegan Community Ecology Package. R Package Version 2.3-5. Available from: https://cran.rproject.org/web/packages/vegan/index.html

Painter D, 1999. Macroinvertebrate distributions and the conservation value of aquatic Coleoptera, Mollusca and Odonata in the ditches of traditionally managed and grazing fen at Wicken Fen, UK. J. Appl. Ecol. 36:33-48.

Pakulnicka J, 2008. The formation of water beetle fauna in anthropogenic water bodies. Oceanol. Hydrobiol. Stud. 37:31-42.

Pakulnicka J, Buczyńska E, Buczyński P, Czachorowski S, Kurztkowska A, Lewandowski K, Stryjecki R, Frelik A, 2015a. Are beetles good indicators of insect diversity in freshwater lakes? Oceanol. Hydrobiol. Stud. 44:487-499.

Pakulnicka J, Buczyński P, Dąbkowski P, Buczyńska E, Stępień E, Szlauer-Łukaszewska A, Zawal A, 2016. Development of fauna of water beetles (Coleoptera) in waters bodies of a river valley - habitat factors, landscape and geomorphology. Knowl. Manag. Aquat. Ecosyst. 417:40. 
Pakulnicka J, Górski A, Bielecki A, 2015b. Environmental factors associated with biodiversity and the occurrence of rare, threatened, thermophilous species of aquatic beetles in the anthropogenic ponds of the Masurian Lake District. Biodivers. Conserv. 24:429-445.

Riis T, Sand-Jensen K, 2001. Historical changes in species composition and richness accompanying perturbation and eutrophication of Danish lowland streams over 100 years. Freshwater Biol. 46:269-280.

Rosset V, Angélibert S, Arthaud F, Bornette G, Robin J, Wezel A, Vallod D, Oertli B, 2014. Is eutrophication really a major impairment for small waterbody biodiversity? J. Appl. Ecol. 51:415-425.

Sánchez-Fernández D, Abellán P, Mellado A, Velasco J, Millán A, 2006. Are water beetles good indicators of biodiversity in Mediterranean aquatic ecosystems? The case of the Segura river basin (SE Spain). Biodivers. Conserv. 15:45074520.

Scheffer M, Achterberg AA, Beltman B, 1984. Distribution of macro $\square$ invertebrates in a ditch in relation to the vegetation. Freshwater Biol. 14:367-370.

Schmidt-Kloiber A, Nijboer RC, 2004. The effect of taxonomic resolution on the assessment of ecological water quality classes. Hydrobiologia 516:269-283.

Spitzenberg D, Sondermann W, Hendrich L, Hess M, Heckes U, 2016. [Rote Liste und Gesamtartenliste der wasserbewohnenden Käfer (Coleoptera aquatica) Deutschlands].[Article in German]. Naturschutz Biol. Vielfalt 70:207-246.

Stein A, Gerstner K, Kreft H, 2014. Environmental heterogeneity as a universal driver of species richness across taxa, biomes and spatial scales. Ecol. Lett. 17:866-880.

Twisk W, Noordervliet MAW, Keurs WJ ter, 2000. Effects of ditch management on caddisfly, dragonfly and amphibian larvae in intensively farmed peat areas. Aquat. Ecol. 34:397-411.

Vaikre M, Remm L, Rannap R, 2015. Macroinvertebrates in woodland pools and ditches and their response to artificial drainage in Estonia. Hydrobiologia 762:157-168.
Vamosi SM, Wohlfahrt B, 2014. Community patterns in Dytiscids, p. 409-436 In: D. Yee D (ed.), Ecology, systematics, and the natural history of predaceous diving beetles (Coleoptera: Dytiscidae). Springer, Dordrecht.

Verdonschot RCM, Didderen K, Verdonschot PFM, 2012a. Importance of habitat structure as a determinant of the taxonomic and functional composition of lentic macroinvertebrate assemblages. Limnologica 42:31-42.

Verdonschot RCM, Keizer-Vlek HE, Verdonschot PFM, 2011. Biodiversity value of agricultural drainage ditches: A comparative analysis of the aquatic invertebrate fauna of ditches and small lakes. Aquat. Conserv. 21:715-727.

Verdonschot RCM, Keizer-Vlek HE, Verdonschot PFM, 2012 b. Development of a multimetric index based on macroinvertebrates for drainage ditch networks in agricultural areas. Ecol. Indic. 13:232-242.

Vlek HE, Verdonschot PFM, Nijboer RC, 2004. Towards a multimetric index for the assessment of Dutch streams using benthic macroinvertebrates. Hydrobiologia 516:173-189.

Vondel BJ van, Dettner K, 1997. Insecta: Coleoptera: Haliplidae, Noteridae, Hygrobiidae, p. 147 In: J. Schwoerbel and P. Zwick (eds.), Süßwasserfauna von Mitteleuropa. Gustav Fischer Verlag, Stuttgart.

Whatley MH, Loon EE van, Dam H van, Vonk JA, Geest HG van der, Admiraal W, 2014. Macrophyte loss drives decadal change in benthic invertebrates in peatland drainage ditches. Freshwater Biol. 59:114-126.

Whatley MH, Vonk JA, Geest HG van der, Admiraal W, 2015. Temporal abiotic variability structures invertebrate communities in agricultural drainage ditches. Limnologica 52:20-29.

Whittaker RH, 1972. Evolution and measurement of species diversity. Taxon 21:213-251.

Williams P, Whitfield M, Biggs J, Bray S, Fox G, Nicolet P, Sear D, 2003. Comparative biodiversity of rivers, streams, ditches and ponds in an agricultural landscape in Southern England. Biol. Conserv. 115:329-341. 